\title{
Dingxin Zhao: The Confucian-Legalist State: A New Theory of Chinese History
}

\author{
Oxford University Press, Oxford, 2015, 474p, £54.99, ISBN: \\ 9780199351732
}

\author{
Jing $\mathbf{L i}^{1}$ (D) \\ Published online: 4 April 2016 \\ (C) Fudan University and Springer Science+Business Media Singapore 2016
}

In this ground-breaking work that explores "overarching patterns of China's past", Zhao Dingxin attempts to address two questions in tandem. First, how and why was China unified and developed into a bureaucratic empire under the state of Qin, after several hundred years of continuous yet inconclusive wars? Second, why, until the nineteenth century, the political-cultural structure of China that was institutionalized during the Western Han era showed such resilience, despite great changes in demography, socioeconomic structure, ethnic composition, market relations, religious landscapes, technology, and topography or brought by rebellions or nomadic conquests (Zhao 2015:6)?

His answers to these questions bear the clear mark of Michael Mann, Charles Tilly and possibly other historical comparativists who engage in "big structures, large processes and huge comparisons" (Tilly 1984). Very briefly, Zhao contends that continuous yet inconclusive wars among states from $770 \mathrm{BC}$ onwards gave rise to instrumental rationalities of political elites and fueled a number of institutional and organizational reforms that greatly expanded state capacities. As a result, the Spring-Autumn and Warring Period was one of the most critical conjunctures for state making in Chinese history. At last, the power structure crystallized into the domination of political power, the subordination of ideological power and military power to political power and the marginalization of economic power, which persisted and continuously shaped and reshaped Chinese history until 1911. This idiosyncratic power structure facilitated and corresponded with a unitary empire (though with short interregnums of political fragmentation) hinging upon

Jing Li

jingli718@fudan.edu.cn

1 Political Science Department, Fudan University, 703 Wenke Building, 220 Handan Rd., Shanghai, China 
Confucian-Legalist ideology. While the Confucian-Legalist State was in its embryo during the Warring Period (chapter 4-7), it took shape after Han dynasty (chapter 9). After the Song dynasty, China turned into a Confucian society, where bureaucratic institutions perfected and local elites were finally suppressed (chapter 12). The Confucian-Legalist State vis-à-vis a Confucian society was so stable that it survived periodical nomadic invasions (chapter 11), the challenges from religions and internal intellectual revolutions (chapter 12), as well as the rise of market economy (chapter 13).

The book has successfully mastered an ambitious topic that sounds too broad to most of the political scientists and sociologists today. It has made remarkable contributions in a number of fronts, including Chinese history, comparative historical studies, state theory, etc. I will just make two points here. Firstly and methodologically, Zhao argues for the so-called "macrostructure informed, mechanism-based study" (Zhao 2015:27). In the intellectual history of social sciences, the obsession with "mechanisms" had a lot to do with the rise of "middlerange theories" originally coined by Merton (1968) during 1960s. At that time, the consolidation of "embedded liberalism" (Ruggie 1982) and the prevalence of positivism urged an empirical turn from macro-theories like that of Parsons to middle-range theories backed by discoveries and tests of mechanisms. However, American scholars soon took for granted the domestic political and social structures within which mechanisms work and applied their theories elsewhere unreflectively. However, mechanisms are by no means general theories; they are profoundly bounded by time, space and structural contexts. Take one of the most popular theories in political science for example. In Bowling Alone, Putnam (2000) contends that the popularization of TV and the professionalization of women after 1960s contributed paradoxically to the decline of US civil society. Plausible as it is, Putnam's theory immediately crumbles if we shift the structural context from US to Nordic countries, where the same mechanism leads to increased public engagement and flourishing of social organizations. The differences lie in structure of political parties, state-society relationship and institutional protection for professional women (Mahoney and Rueschemeyer 2003).

Zhao is definitely well aware of the pathologies of contemporary social science. By applying "macrostructure informed mechanism-based study", he re-embeds mechanisms into the unique power structure characterizing ancient China. Let me elaborate. In the classical works of war making and state making in Western Europe, Tilly (1990), Downing (1992) and others argue that the natural selection mechanism of war gave rise to the domination of modern state. Zhao, however, meticulously analyzes how this mechanism unfolds in Chinese context in a different fashion. For example, while the accumulation and concentration of both coercion and capital were crucial for state building in the West, state building in China had only one leg, i.e., coercion rather than capital, for trade networks and cities were largely marginalized if not downright underdeveloped in ancient China; while Europe evolved into an international system of national states of medium size, China united into an colossal and effective empire mastering over a huge territory; while the state building process in Europe was characterized by the contentions among various 
elites of different power bases, in China political elites had the upper hand from the very beginning and continued to dominate other social groups.

Second, Zhao's work has also greatly enriched the scholarship on state building. Most of the previous works implied but largely failed to articulate the exact relationship between modern state building and a number of paralleling historical movements, e.g., the rise of industrial capitalism, the rise of nation and nationalism, the co-option of major elites into the national political platform and possibly, the rise of representative democracy. Their theories of state formation and state building have deeply entangled with one or several of these macroprocesses, thus representing only one particular path for state building. Zhao's book, however, examines an alternative path where all of the three processes listed above were absent. First, as Zhao rightfully explains, there is only market economy rather than industrial capitalism in Chinese history, which resulted from the marginalization of economic power and merchants. Second, as nationalism was the product of modern industrialism and "high culture" in the first place (Gellner 1983), state building in most of the ancient Chinese history proceeded without the cultural resources of nation building. In comparison, state building and nation building coincided with each other in the Western context. Last, elites in Chinese history seem to be much more homogenized and undifferentiated when comparing with Europe, where the fall of Roman empire and the perennial feudal institutions left a highly fragmented elite structure. Hence, Chinese politics allowed little space for political contestation and the prospect for representative democracy was dim. Taking together, when a homogenous, unrivaled group of political elites came to build Chinese state in absence of modern capitalism and modern forms of human collectivity, a united empire informed by Confucian-Legalist ideology and centered on state power was probably the "inevitable accident" of history. Zhao's work, together with numerous others that brought in non-Western experiences of state building, amply exemplify the multiplicity of paths for state building (King and Lieberman 2009).

Despite its methodological contribution and impressive narratives on alternative path for state making, Zhao's work can also be improved in at least two ways. First, Confucian-Legalist State is nevertheless plagued by structural reductionism. Zhao has definitely resuscitated the long-marginalized tradition of the first wave of historical-comparative studies that merit macrostructure, but simultaneously he shares their determinism of various sorts as well as failure to introduce and seriously analyze "agency". The third part on Spring-Autumn and Warring Period appears to be much more "agency sensitive" by attending to rational choices of political elites, whereas the fourth part is all about the omnipresent state power and the continuous reproduction of the basic power structure. We cannot help but ask: how did agents gain or lose power at the micro-level? what were their interests, calculations and strategies? how did they make decision regarding whether to comply or to revolt? what were their world views and discourses? etc. Comparatively, although Tilly was accused of structuralism on numerous occasions, his theory of state formation was supplemented by an independent theory of contentious politics (Tilly et al. 2009), thus combining structure and agency, just like two sides of one coin. Zhao's theoretical framework, however, allows far less agency. 
Besides, Zhao equally fails to attend to potential structural transformations in history. Indeed, as one of Zhao's major theoretical sources, Michael Mann deals with change much better than Zhao by proposing the interstitial origin of powers. Following his conceptualization, the power structure is always subject to change and hence power elites will be constantly reshuffled (Mann 1986). In other words, Zhao applies only the first half of Mann's theory, i.e., four sources of social power, while intentionally or unintentionally neglecting the second half, i.e., about change and restructuration. In Zhao's book, we have witnessed the continuous production and reproduction of an inflexible power structure throughout most of the Chinese history. But numerous historical works have already argued otherwise. The cyclical restoration of a unified Confucian-Legalist State prioritizing political power is more of a historical contingency than inevitable fate. In fact, Chinese history has always been full of heterogeneity and windows of opportunities for change. They cannot be simply explained away. They form alternative traditions that flow like undercurrents and resurface from time to time. A better theory of both structure formation and structural transformation should deal with them tirelessly.

\section{References}

Downing, Brian M. 1992. The military revolution and political change: origins of democracy and autocracy in early modern Europe. Princeton: Princeton University Press.

Gellner, Ernest. 1983. Nations and Nationalism, new perspectives on the past. Ithaca: Cornell University Press.

King, Desmond, and Robert C. Lieberman. 2009. Ironies of state building: a comparative perspective on the American state. World Politics 61: 547-588.

Mann, Michael. 1986. The sources of social power. Cambridge Cambridgeshire; New York: Cambridge University Press.

Merton, Robert King. 1968. Social theory and social structure. New York: Free Press.

Putnam, Robert D. 2000. Bowling alone: the collapse and revival of American community. New York: Simon and Schuster.

Ruggie, John Gerard. 1982. International regimes, transactions, and change: embedded liberalism in the postwar economic order. International Organization 36: 379-415.

Tilly, Charles. 1984. Big structures, large processes, huge comparisons, Russell sage foundation 75th anniversary series. New York: Russell Sage Foundation.

Tilly, Charles. 1990. Coercion, capital, and European states, Ad 990-1990. Cambridge: Basil Blackwell. Tilly, Charles, Lesley J. Wood, and Charles Tilly. 2009. Social movements, 1768-2008, 2nd ed. Boulder: Paradigm Publishers.

Zhao, Dingxin. 2015. The Confucian-Legalist State: a new theory of Chinese history, Oxford studies in early empires. Oxford: Oxford University Press. 